\title{
Analiza opisów przedmiotu, postaci i krajobrazu napisanych przez uczniów klas IV-VI szkoły podstawowej
}

Opis, wraz z opowiadaniem, streszczeniem, dyskusją, rozprawką, przemówieniem, sprawozdaniem czy charakterystyką, należy do podstawowych form wypowiedzi szkolnych ${ }^{1}$. Jest on formą wypowiedzi łatwą do zidentyfikowania ze względu na swoje charakterystyczne cechy. Zazwyczaj wymaga kompozycji co najmniej trójdzielnej, na którą składa się wstęp, rozwinięcie i zakończenie, dopuszcza ocenę i różne ujęcia tematu, może zatem przyjmować zróżnicowane formy stylistyczne ${ }^{2}$.

Kształcenie umiejętności tworzenia opisu w szkole ma ponadprzedmiotowy wymiar praktyczny. Ćwiczenia w opisywaniu przyczyniają się do wzrostu umiejętności analizy i syntezy, precyzji przekazywania informacji, a także rozwijają słownictwo potrzebne do określania cech lub uczućc ${ }^{3}$. Opisy pisane na lekcjach to zarówno samodzielne teksty, których hipertematem jest przedmiot opisu, jak i część składowa innych form wypowiedzi szkolnej, najczęściej opowiadania. W klasach młodszych opisu uczy się jako elementu rozmowy ${ }^{4}$.

${ }^{1}$ J. Bar, Szkolne formy wypowiedzi, [w:] Wybrane zagadnienia edukacji polonistycznej, red. H. Kurczab, U. Kopeć, E. Kozłowska, Rzeszów 2002, s. 207.

2 J. Kulpa, W. Pasterniak, Metodyka nauczania języka polskiego, Warszawa 1977, s. 109, 112.

${ }^{3}$ M. Nagajowa, ABC metodyki języka polskiego, Warszawa 1995, s. 91.

${ }^{4}$ M. Nagajowa, Jak uczyć języka polskiego w klasach 4-6. Poradnik metodyczny do podręczników „, Stowo za stowem”, „Stowa zwykle i niezwykle”, ,, Stowa i świat”, Warszawa 1995, s. 91. 


\section{Definicja i struktura opisu ${ }^{5}$}

W naukach humanistycznych opis definiuje się w ujęciu szerokim bądź wąskim. W ujęciu szerokim, wywodzącym się ze starożytnej retoryki, opis jest gatunkiem, który może występować samodzielnie lub jako składnik innego gatunku, jest więc w takim rozumieniu właściwy nie tylko tekstom literackim. W ujęciu wąskim opis traktowany jest jako kategoria dzieła literackiego ${ }^{6}$. Teoria literatury wypracowała między innymi następującą definicję opisu:

Opis — jeden z dwu podstawowych obok opowiadania elementów narracji, w liryce zaś jeden z komponentów monologu lirycznego. W przeciwieństwie do opowiadania opis przedstawia tło, na którym przebiegają wydarzenia, wygląd postaci itp.; jest w zasadzie ujęciem pozaczasowym, ukazuje składniki i właściwości danego przedmiotu w statyczności i — szczególnie często — w usytuowaniu przestrzennym ${ }^{7}$.

Opis w ujęciu szerokim definiuje między innymi Jozef Mistrík „to wypowiedź, której nadawca skupia się na własności rzeczy lub zjawiska, a przy tym przedstawia je tak, jakby je widział własnymi oczyma; opis jest gatunkiem mowy związanym z wrażeniem, jakie świat wywiera na nasze zmysły"8. Z kolei Aleksander Wilkoń podaje następującą definicję: „tekst deskryptywny werbalizuje świat w perspektywie ponadczasowej, omnitemporalnej i habitualnej, skupiając się przede wszystkim na właściwościach, stanach i długo trwających procesach (czynnościach duratywnych)"9. Stwierdza też, że „opis nie jest gatunkiem, ani nawet rodzajem, ale formą podawczą wypowiedzi, w których zawsze in potentia może się pojawić"10, czym przeciwstawia się ujęciu Mistríka Wilkoń wymienia cechy charakterystyczne zdań opisowych; są to: 1 . predykcja wyrażona czasownikami stanowymi, habitualnymi, omnitemporalnymi, duratywnymi, 2. formy praesens tych czasowników bądź też formy czasu przeszłego niedokonanego, 3. różnorodne przydawki i wyrażenia, na przykład spacjalne ${ }^{11}$.

Opis zazwyczaj przybiera strukturę diagramatyczną, to znaczy przedstawia rzeczywistość w tak zwanym ordo naturalis — bieg zdań w tekście odwzorowu-

${ }^{5}$ W lingwistyce tekstu oprócz terminu 'opis' pojawiają się też określenia 'tekst deskryptywny' lub 'deskrypcja', w niniejszym artykule, w którym wiążę dorobek lingwistyki tekstu z metodyką, terminy te będą stosowane zamiennie, pojęcia 'deskrypcja'/ 'tekst deskryptywny' stosują m.in. A. Wilkoń, B. Witosz, U. Żydek-Bednarczuk, por. A. Wilkoń, Spójność i struktura tekstu. Wstęp do lingwistyki tekstu, Kraków 2002, s. 135-157; B. Witosz, Opis w prozie narracyjnej na tle innych odmian deskrypcji. Zagadnienia struktury tekstu, Katowice 1997; U. Żydek-Bednarczuk, Wprowadzenie do lingwistycznej analizy tekstu, Kraków 2005, s. 135-152.

${ }^{6}$ B. Witosz, op. cit., s. 21.

${ }^{7}$ Stownik terminów literackich, red. J. Sławiński, wyd. 3 poszerz. i popr., Wrocław 2000, s. 358 .

8 J. Mistrík, Štylistika, Bratislava 1985, s. 351; cyt. za: B. Witosz, op. cit., s. 22.

${ }^{9}$ A. Wilkoń, op. cit., s. 109.

10 Ibidem, s. 138.

${ }^{11}$ Ibidem, s. 137. 
je bieg zdarzeń naturalnych ${ }^{12}$. Zasadniczo struktura opisu podporządkowana jest temu, czemu opis ten ma służyć i jakie informacje przekazać, oraz sferze komunikacyjnej, w której ten opis się pojawia, to znaczy, czy jest to opis na przykład naukowy, potoczny, czy literacki. Na każdy opis składają się jednak ,jednostki wypowiedzi przypisujące cechy jakiemuś obiektowi"13.

Wilkoń zauważa, że makrotemat opisu może być rozbijany na kolejne tematy, a te na mikrotematy ${ }^{14}$. Tworzy się w ten sposób układ: ogólne - mniej ogólne — szczegółowe, to znaczy zachodzi stopniowe zawężanie tematu. Mówić można wtedy o tak zwanym układzie zstępującym. W tego typu kompozycji główny temat podawany jest $\mathrm{w}$ tytule lub $\mathrm{w}$ zdaniach inicjalnych ${ }^{15}$. Układ zstępujący może zostać odwrócony i powstanie wtedy układ wstępujący, w którym elementy pojawiają się w następującej kolejności: szczegółowe — bardziej ogólne — ogólne. Makrotemat (hipertemat) umieszczony jest wtedy na końcu partii deskrypcyjnej lub na końcu opisu i pełni funkcję pointy, konkluzji lub syntezy ${ }^{16}$.

Dodawanie kolejnych elementów do opisu przybiera zazwyczaj charakterystyczną dla tej struktury parataktyczną formę wyliczenia ${ }^{17}$. Poszczególne obiekty w takim wyliczeniu mogą być połączone w kolekcję, która zawiera w sobie przedmioty występujące $\mathrm{w}$ jednym miejscu $\mathrm{i}$ czasie oraz biorące udział $\mathrm{w}$ jednym zdarzeniu w taki sam sposób ${ }^{18}$. Opis może przybrać też budowę szkatułkową, gdy pewna partia tekstu podporządkowana nazwie nadrzędnej buduje jakby odrębny opis, który mógłby istnieć poza tekstem źródłowym. Widać zatem, że rozwinięcie tematyczne deskrypcji nie zawsze przebiega linearnie, temat często jest powielany i wzbogacany o kolejne elementy, a tym samym się modyfikuje ${ }^{19}$. W tym przypadku można mówić o tematycznej progresji prostej, która polega na budowaniu tematu $\mathrm{w}$ relacji bezpośredniej ciągłości, znaczenia tekstowe budowane są sekwencyjnie i przez dodawanie, co utrudnia odgadywanie znaczeń globalnych ${ }^{20}$.

\section{Analiza uczniowskich opisów}

Artykuł ten poświęcony jest analizie wybranych aspektów opisów tworzonych na lekcjach języka polskiego przez uczniów klas 4-6. Autorka szczególnie skupiła się na badaniu:

12 A. Duszak, Tekst, dyskurs, komunikacja międzykulturowa, Warszawa 1998, s. 45-46.

${ }^{13}$ B. Witosz, op. cit., s. 58.

14 A. Wilkoń, op. cit., s. 143.

15 Ibidem, s. 144.

16 Ibidem.

17 Ibidem, s. 146.

18 Ibidem, s. 156.

${ }^{19}$ U. Żydek-Bednarczuk, op. cit., s. 140.

${ }^{20}$ A. Duszak, op. cit., s. 184. 
— porządku elementów opisu, czyli zgodności kolejności przywoływanych treści z przyjętym planem kompozycyjnym ${ }^{21}$;

— poziomu zagłębienia ${ }^{22}$ opisów, czyli liczby elementów składowych, które zostały w opisie przywołane i scharakteryzowane, oraz dokładności przedstawienia obiektu.

Wśród badanych teksów znalazły się opisy postaci, przedmiotu i krajobrazu, łącznie osiemdziesiąt osiem prac zebranych w latach 2014-2016.

\subsection{Porządek elementów opisu}

\section{Opisy postaci}

Do przedstawienia cech postaci najbardziej typową jest kompozycja od całości do szczegółów, a następnie od góry do dołu.

Kompozycja od całości do szczegółów zachowana jest w dwudziestu z czterdziestu trzech analizowanych opisów postaci.

1. Mama jest mocno zbudowana i średniego wzrostu.

Ma włosy koloru kruczego i jasno-brązowe końcówki. Ma brązowe oczy, duży nos i pełne usta. Jej znak rozpoznawczy to okulary.

2. Mama Ania ma smukłą sylwetkę, jest bardzo chuda.

Moja mama ma bląd włosy, mały garbaty nos, niebieskoszare oczy, i małe usta ${ }^{23}$.

3. Wiktoria ma 12 lat jest niewysoką, szczupłą i bardzo wysportowaną dziewczyną. Ma owalną twarz, po której spływają ciemne blond długie włosy. Ma duże brązowe oczy i ładne usta.

4. Jest dość wysoką, szczupłą, blondynką o krótkich włosach. Ma niebieskie oczy, długie rzęsy i różowe usta, które maluje swoją malinową pomadką.

W podanych przykładach uczniowie najpierw przedstawiają całą postać, eksponując te cechy, które są najłatwiej dostrzegalne, widziane z oddali (charakteryzują sylwetkę i wzrost opisywanej osoby), a potem skupiają się na twarzy, co wymaga dokładniejszego przyjrzenia się opisywanej osobie. Jest to kolejność zgodna z najczęstszym sposobem opisywania osób w potocznej konwersacji.

Sześcioro uczniów wybrało porządek od szczegółu do ogółu, zaczynając od opisu twarzy jako elementu najbardziej indywidualizującego człowieka, a następnie określiło cechy całej sylwetki:

${ }^{21}$ Typy układów kompozycyjnych w szkolnych gatunkach wypowiedzi zdefiniowała między innymi Halina Wiśniewska, wyróżniając dla opisu kompozycję hierarchiczną, horyzontalną, zegarową oraz porządek „od głów do stóp”, por. H. Wiśniewska, Łatwa i trudna kompozycja pisemnych wypracowań uczniowskich, [w:] Wokół szkoły i nauczyciela. Skrypt dla studentów filologii polskiej, red. H. Wiśniewska, J. Plisiecki, Lublin 1997, s. 124.

22 Termin stworzony na potrzeby przeprowadzonych badań; pojęcie „zagłębienie” nawiązuje do wypracowanych przez lingwistykę tekstu kategorii, jak: następstwo tematyczne tekstu, rozwijanie tematu w tekście, makrostruktura tekstu oraz typy relacji opisowych; por. J. Bartmiński, S. Niebrzegowska-Bartmińska, Tekstologia, Warszawa 2009, s. 266-267, 277-282; A. Wilkoń, op. cit., s. 143-145.

${ }^{23} \mathrm{~W}$ przykładach zachowano oryginalną pisownię. 
5. Ma żółto-czarne włosy. Duży purkaty nos, duże mocno czerwone usta. Brązowe oczy i małe uszy. Mama ma owalną głowę.

Jest chuda i bardzo wysoka, ma miękką skórę.

6. Mama ma okrągłą twarz, a na niej niebieskie oczy z długimi czarnymi rzęsami, lekko różowe usta i zarumienione policzki.

Ma krótkie brązowe włosy z grzywką na bok którą codziennie prostuje.

Mama jest wysoka, chodzi energicznie.

Porządku takiego nie można uznać za niewłaściwy i nielogiczny. Uczniowie, którzy wybierali taką kompozycję opisu postaci, przyjmują perspektywę zwiększania dystansu, oddalania się od osoby, aby zauważyć całość. Łatwiej też było im przejść od charakteryzowania sylwetki do określenia sposobu ubierania się, ponieważ te dwa aspekty są z sobą kojarzone.

W ośmiu pracach uczniowie zupełnie pomijają ogólną charakterystykę sylwetki postaci, skupiając się jedynie na twarzy. Opis postaci jest przez to niepełny, ponieważ nie zawiera informacji podstawowych, choć najmniej indywidualizujących, ale ułatwiających rozpoznanie przedmiotu opisu.

Drugim sposobem uporządkowania elementów opisu jest porządek od góry do dołu, czyli w przypadku opisu człowieka od głowy do stóp. Kompozycja wertykalna pojawia się, kiedy uczniowie opisują twarz. Trudno jednak jednoznacznie ocenić świadomość zastosowania tej kompozycji, ponieważ uczniowie nie wymieniają wszystkich części twarzy. Za szczegółowy i przemyślany kompozycyjnie można uznać ten fragment:

7. Twarz ma pociągłą i piegowatą. Czoło wysokie. Oczy Kamila są brązowe i duże. Pod nimi znajduje się zadarty nos. Usta Kamila są małe i wąskie, a gdy się denerwuje często je zagryza, pokazuje przy tym swoje białe zęby.

Uczeń charakteryzuje tu twarz najpierw globalnie, a potem przechodzi do jej części składowych, wymieniając prawie wszystkie we właściwej kolejności.

Jednakże im więcej elementów uczniowie wymieniają, tym trudniej im je uporządkować zgodnie z budową anatomiczną ludzkiej głowy, dlatego też kompozycja sprawia wrażenie nieuporządkowanej. Zaburzenie to może wynikać z nieumiejętności właściwego uszeregowania poszczególnych elementów lub być przejawem trudności, jaką jest dla ucznia znalezienie właściwych określeń na poszczególne części twarzy. Pisząc, uczeń zaczyna więc od tego, co jest najłatwiej dostrzegalne, następnie przechodzi do tego, co jest trudniejsze do scharakteryzowania lub mniej widoczne. Prawdopodobnie informacje te umieszcza w celu zrealizowania schematu poznanego na lekcji i jak najdokładniejszego opisania postaci.

8. Moja mama jest wyjątkowa bo ma: okrągłą głowe z garbiony nos, duże uszy, ładne niebieskie oczy, czarne mocne włosy (oczywiście pszefarbowane), duże czerwone usta.

9. Ma zielone oczy czerwone usta i szpiczasty nosek oraz brązowe włosy.

10. Jej oczy są koloru niebieskiego. Ma sarnie spojrzenie. Ma troche ciemne blond włosy. Jej uszy są średnie. Ma średnie usta, które są naturalne. Jej buźa jest ma owalny kształt. 
W powyższych przykładach uczniowie charakteryzują cztery i więcej elementów, odbiegając od porządku z góry na dół, który mógłby przedstawiać się następująco: włosy, oczy, nos, uszy, usta. Zauważyć można, że pierwszej z wymienionych części ciała towarzyszy najbardziej konkretna cecha, najłatwiejsza do zdefiniowania (,ma okrągłą głowe”, „ma zielone oczy”, ,jej oczy są koloru niebieskiego") oraz pewna nieokreśloność cech podawanych w drugiej kolejności: „duże”, „średnie”.

Pozorny nieporządek od góry do dołu może być też przejawem zastosowania układu hierarchicznego, czyli od tego, co najbardziej charakterystyczne dla danej osoby, do tego, co jest elementem mniej istotnym, szczególnie z perspektywy piszącego. Schemat ten obrazuje poniższy przykład:

11. Wszyscy zachwycają się jego wielkimi, brązowymi jak czekolada oczami, zaś mi najbardziej podobają się jego piękne, malinowe usta. Uwielbiam je, choć moja siostra cały czas powtarza, że najpiękniejszy u taty jest jego nos. Choć lekko piegowaty i spiczasty to bardzo ładny.

Uczennica najpierw wymienia oczy ojca, ponieważ one zwracają uwagę wielu ludzi, są dla niego najbardziej charakterystyczne. Następnie opisuje usta, które według niej są elementem o najwyższych walorach estetycznych. Na końcu wymienia nos, wspomina więc o elemencie, który zwraca czyją́s uwagę, ale dla niej nie jest najważniejszy, polemizując tym samym z siostry oceną wyglądu ojca.

Warto przyjrzeć się też porządkowi globalnemu analizowanych opisów i ich zgodności z wzorcem kompozycyjnym. Przyjęto następujący porządek tego typu wypowiedzi szkolnej: 1. ogólne przedstawienie postaci, 2. opis sylwetki, 3. opis poszczególnych części ciała, 4. opis ubioru, 5. opis sposobu zachowania, usposobienia itp., 6. podsumowanie zawierające opinie o opisywanej osobie ${ }^{24}$. Obrazują go poniższe przykłady:

12. Moja mama ma na imię Kornelia. Ma czterdzieści lat.

Ma szczupłą sylwetkę. Jest średniego wzrostu.

Jej oczy są niebieskie. Nos jest średniej wielkości. Usta mają różowy kolor. Mama nie ma nigdy makijażu. Jej włosy mają bardzo ciemny, brązowy kolor, sięgają jej przed ramiona. Mama nosi okulary.

Zazwyczaj ubiera bluzki z nadrukami lub wzorami. Chodzi tylko w spodniach.

Jest miła, choć czasem gdy się wkurzy krzyczy na mnie i moje rodzeństwo. Moja mama jest najukochańsza na świecie.

13. Mój najlepszy przyjaciel nazywa się Michał P[...]. Ma dwanaście lat i chodzi do klasy 6a. Jest szczupły i wysoki. Ma gęste brązowe włosy, niebieskie duże oczy oraz średni nos z piegami. Naprawdę całą twarz ma w piegach. Najczęściej ubiera się w bluzy i „rurki”. Jego największym atutem jest to, że nigdy się nie poddaję. Jest oschły dla niektórych osób. Najbardziej lubi matematykę. Razem ze mną chodzi na wszystkie zawody sportowe. Obaj kibicujemy jednej drużynie piłkarskiej. Według mnie jest koleżeński i wytrwały. Można mu zaufać.

W przytoczonych przykładach widać zgodność z wzorcowym uporządkowaniem kompozycyjnym (pomijam tu poprawność segmentacji i kolejność elemen-

${ }^{24}$ Por. S. Borowkin, Stownik terminów piśmienniczych, Kielce 1997, s. 55-56; J. Kowal, O sztuce pisania wypracowań. Dialog, list, opis, opowiadanie, rozprawka, sprawozdanie, streszczenie, charakterystyka postaci, Kielce 1994, s. 31-32. 
tów składowych opisu), uczniowie realizują po kolei segmenty, choć poziom ich rozwinięcia nieraz jest nieproporcjonalny. W przeważającej części analizowanych prac panuje porządek kompozycyjny, mimo że czasami odwrócona jest kolejność segmentów (wygląd postaci przedstawiony od szczegółu do ogółu) lub niektóre segmenty wzorca kompozycyjnego są pomijane, jak w poniższym tekście:

14. Mój tata ma na imię Maciej i ma 50 lat.

Ma bardzo wysportowaną sylwetkę, bo tak jak ja gra w piłkę nożną.

Wszyscy zachwycają się jego wielkimi, brązowymi jak czekolada oczami, zaś mi najbardziej podobają się jego piękne, malinowe usta. Uwielbiam je, choć moja siostra cały czas powtarza, że najpiękniejszy u taty jest jego nos. Choć lekko piegowaty i spiczasty to bardzo ładny.

Maciek ubiera się normalnie. Nie ma w zwyczaju stania godzinami przed lustrem.

Wiadomo, że tatusiowie bywają różni. Lecz ja wiem, że mojemu mogę zaufać. Ma on trudny charakter, ale przyzwyczaiłam się do niego. Kocham go z całego serca.

W przykładzie 14 uczennica nie poświęca uwagi zwyczajom, usposobieniu czy charakterowi opisywanej osoby, jedyne w podsumowaniu pojawiają się wzmianki na ten temat. Pominięcie jednego segmentu nie wpływa znacznie na jakość opisu.

W kolejnym przykładzie widać umieszczenie jednego z segmentów przedstawienia postaci $\mathrm{w}$ innym miejscu tekstu niż wynika to $\mathrm{z}$ wzorca:

15. Moją najlepszą przyjaciółką jest Wiktoria M[...]. Mieszka niedaleko mnie, dlatego często się spotykamy. Gdy do niej przychodzę nam się nie nudzi. Jest niewysoką, szczupłą blondynką o jasnej cerze. Twarz ma drobną, a oczy koloru piwnego. Lubi ubierać luźniejsze rzeczy. Preferuje ciemnego koloru ubrania, dlatego często można ją zobaczyć w czarno-szarych kreacjach. Znamy się od 6 lat i jesteśmy bardzo zżyte. Wiem, że jeśli powierzę jej jakiś sekret — jest on bezpieczny. Interesuję się tańcem i w wolnych chwilach chodzi na zajęcia taneczne. Często odwiedzam ją na treningach i uważam, że ma wielki talent. Wiktoria zawsze ma dobry humor i często śmiejemy się z rzeczy błahych i niemających dla innych większego znaczenia. Nigdy nie przejmuje się tym, co inni o niej mówią i myślą. Bardzo ją lubię i cieszę się, że mam taką wspaniałą przyjaciółkę. Mam nadzieję, że nadal będziemy się przyjaźnić.

Przyjmuje się, że informacja o czasie trwania znajomości z opisywaną osobą powinna zostać podana $\mathrm{w}$ części wstępnej. W przytoczonym przykładzie pojawia się zaś po informacji o wyglądzie zewnętrznym, co można byłoby potraktować jako pomyłkę w uporządkowaniu tekstu. Jednak uczennica świadomie wprowadza wzmiankę o czasie trwania przyjaźni właśnie tym miejscu, ponieważ wiąże ją z dalszym tokiem rozważań. Widać więc, że nie każde odejście od wzorca gatunkowego należy uznać za błąd.

W dziewięciu pracach uporządkowanie kompozycji zostało zaburzone, co oznacza, że zmiana kolejności wynikającej z planu kompozycyjnego tekstu wzorcowego nie wpływa pozytywnie na jakość opisu, ponieważ nie służy trafniejszemu przedstawieniu cech postaci. Zaburzenia te widoczne są zarówno na poziomie zdania, jak i całego tekstu.

16. Mama ma na imię Agnieszka i ma 39 lat. Jest brunetką z jasnymi pasemkami. Jest średniego wzrostu i pracuje w sklepie odzieżowo-zabawkowym i pielęgnuje swoje włosy. 
Uczeń we wstępnej prezentacji postaci łączy cechy, które są z sobą logicznie niepowiązane, pisze o pierwszych wrażeniach dotyczących wyglądu osoby (kolor włosów i wzrost), po czym informuje o jej zatrudnieniu i przechodzi do opisu zwyczajów. Wszystkie te informacje mogłyby pojawić się w pierwszym akapicie, jednak uczeń powinien zwrócić uwagę na ich logiczno-językowe uporządkowanie uzasadniające umieszczanie ich w części wstępnej.

17. Marian Marianowski ma 12 lat i interesuje się sportem. Jego włosy mają kolor czarny. Ma niebieskie, duże oczy, zgrabny nos i krótką szyję. Marian często chodzi w kolorowych bluzach i ciemnych spodniach dresowych. Ma długie nogi. Dzięki swoim nogom biega bardzo szybko. Na jego stopach zawsze znajdują się adidasy. Śmieje się jak wiewiórka. Marian jest mądry, odważny oraz miły. Nie lubi, gdy się o nim mówi kujon. Jednak wszyscy go lubią za to, że jest miły. Nikt nie boi się przy nim iść gdy jest ciemno. Moim zdaniem to bardzo dobry kolega.

W przykładzie 17 uczeń przedstawia opisywaną osobę i we wstępie określa jej zainteresowania, co można jeszcze uznać za stosowne. Następnie po opisie głowy charakteryzuje zwyczajowy strój postaci i przechodzi do informacji o predyspozycjach („,biega bardzo szybko”), po czym znów wraca do ubioru („Na jego stopach zawsze znajdują się adidasy"). Wprowadzane tematy szczegółowe należałby uporządkować, aby logicznie łączyły się w tematy segmentów.

18. Moja mama ma 39 lat. Mama jest miła, przyjacielska, ma metr 60 wzrostu. Ubiera się w ciemne koszulki i dżinsy. Moja mama lubi spagetii z sosem pomidorowym i kukurydzą mama lubi do picia polaris truskawkowe. Moja mama ma brąnzowe oczy, czerwone włosy, spiczasty nosek. Mama ma charakter dobry i miły.

W cytowanym przykładzie widać całkowite nieuporządkowanie tekstu, zarówno w płaszczyźnie globalnej, jak i lokalnej. Uczeń w jednym zdaniu łączy informacje o usposobieniu i wzroście, przechodzi do preferencji żywieniowych, a potem, jakby w wyniku przypomnienia sobie o konieczności opisana wyglądu, charakteryzuje oczy, włosy i nos. Na końcu znowu wraca do cech charakteru. Omawiany opis jest przy tym bardzo krótki, widać, że uczeń nie radzi sobie z tą formą wypowiedzi. Nie potrafi wyodrębnić i nazwać cech zewnętrznych i wewnętrznych człowieka, ma też problem z uporządkowaniem własnego tekstu według przyjętego wzorca.

Porządek elementów opisu postaci sprawia uczniom niewielki problem, zwłaszcza jeśli chodzi o uporząakowanie elementów szczegółowych; pojawiają się one często w kolejności od tego, co uczniowi najłatwiej określić, do tego, co trudniejsze do scharakteryzowania. Jeśli zaś chodzi o globalny porządek kompozycyjny, to uczniowie radzą sobie z uporządkowaniem segmentów, kolejno wprowadzane przez nich tematy akapitów lub zdań odpowiadają porządkowi wzorca, prace są przez to zbliżone pod względem treści i budowy.

\section{Opisy przedmiotu}

W opisach przedmiotów, które są analizowane w niniejszej pracy, nie można mówić o kompozycji horyzontalnej lub wertykalnej. Uczniowie przedstawiają 
cechy przedmiotu zazwyczaj globalnie. Następnie skupiają się na opisaniu jakiejś jego części, ale zabieg ten pojawia się tylko w nielicznych pracach. $Z$ tego powodu w tej części przeanalizuję kolejność podawania poszczególnych cech i sprawdzę, czy jest ona stała i przemyślana czy raczej przypadkowa.

Uczniowie wymieniają od dwóch do sześciu cech opisywanego przedmiotu, nie są one jednak uporządkowane w stały sposób, kolejność cech zależy od autora pracy. W 7 z 23 prac uczniowie zaczynają opis od określenia, skąd pochodzi przedmiot, w jakich okolicznościach autor stał się jego właścicielem. Informację tę umieszczają w akapicie wstępnym lub w pierwszym bądź drugim zdaniu, gdy tekst nie jest poddany segmentacji, np.:

19. Moim ulubionym ubraniem jest sweter który kupiłem w sklepie z ciuchami.

20. Moim ulubionym przedmiotem jest rower. Dostałem go na 8 urodziny od moich rodziców.

21. Opiszę obraz namalowany przez mojego tatę.

Określenie pochodzenia przedmiotu jest dobrym sposobem na zbudowanie wstępu. Często uzasadnia wybór przedmiotu opisu oraz dookreśla opisywaną rzecz, wyróżniając ją spośród wielu innych tego samego typu.

W czterech pracach jako pierwszą cechę uczniowie podają kształt i wielkości przedmiotu. To właściwości najłatwiejsze do określenia i najlepiej charakteryzujące przedmiot na poziomie globalnym, choć czasem oczywiste dla opisywanego przedmiotu, jak w poniższych przykładach:

22. Mój kubek ma kształt kubka [...]

23. Opisuję deskorolkę.

Jest kształtu spłaszczonego koła.

Czworo uczniów zaczyna pracę od określenia, do czego przeznaczony jest opisywany przedmiot. Informację tę umieszczają w akapicie wstępnym, co ułatwia wprowadzenie w temat:

24. Mój piórnik pomaga mi w noszeniu rzeczy.

25. Moją ulubioną rzeczą jest piłka do grania w piłkę nożną.

W dwóch pracach pierwszą wymienioną cechą jest materiał, z którego przedmiot wykonano, troje uczniów zaczyna opisywanie przedmiotu od podania, w jakim jest on kolorze bądź kolorach.

W siedmiu pracach drugą właściwością opisywanego przedmiotu jest kształt lub wielkość, w trzech pracach informacja ta pojawia się bezpośrednio po określeniu pochodzenia przedmiotu, $w$ dwóch po informacji o przeznaczeniu przedmiotu oraz w dwóch po zdefiniowaniu koloru. Sześcioro uczniów jako drugą cechę podało kolor opisywanego przedmiotu, dwoje z nich zrobiło to po określeniu kształtu, inni po informacji o materiale, z którego rzecz jest wykonana, wyjaśnieniu pochodzenia przedmiotu, po wskazaniu technicznej właściwości („,dotykowy telefon") i zdefiniowaniu marki przedmiotu.

W trzech pracach jako druga cecha pojawia się materiał, z którego wykonano opisywany przedmiot, pierwszą cechą $\mathrm{w}$ tych opisach jest pochodzenie przedmiotu. 
W jednej z prac po określeniu czasu posiadania przez autora opisywanej rzeczy pojawia się wartościowanie:

26. Mój piórnik mam już dwa lata. Bardzo jest fajny i funkcjonalny.

To bardzo ładny piórnik.

następnie podane są cechy postrzegane obiektywnie, takie jak kolor, materiał itp.

Uczniowie, opisując przedmiot, zaczynają więc od cech, które są zauważalne od razu i umożliwiają identyfikację przedmiotu, wyodrębnienie go ze zbioru wielu innych tego samego typu. Są to zazwyczaj właściwości odbierane za pomocą wzroku. Takie uporządkowanie cech sprawia, że uczniowskie teksty są opisami rzeczowymi.

\section{Opisy krajobrazu}

Analizując porządek elementów opisu krajobrazu, należy rozpatrzeć usytuowanie przestrzenne obiektów tworzących ten krajobraz i to, jak jest ono odzwierciedlone w tekście.

Uczniowie, opisując krajobraz przedstawiony na fotografii, najczęściej łączą kompozycję hierarchiczną i horyzontalną. Zaczynają więc od scharakteryzowania pierwszego planu, a następnie, gdy przechodzą do kolejnych planów, zaczynają od elementów, które dla danego planu są najbardziej istotne i uzupełniają o te wymagające uważniejszego przyjrzenia się zdjęciu.

27. Gdy uniosłam wzrok, ujrzałam piękny krajobraz miejski, na którym się naprawdę wiele dzieje. Na pierwszy rzut oka widać, że to jesienny krajobraz, gdyż drzewa prawie w ogóle nie mają liści lub są one w ciemnych kolorach.

Na pierwszym planie znajduje się mały staw, bądź rzeka. W tafli wody odbijają się lekko rozmazane budynki i skrawek nieba. Większość miejsca zajmuje niebo w różnych odcieniach błękitu. W niektórych miejscach nachodzą na nie wysokie budynki. Budowle te są kilkunastopiętrowe. Dwa z nich to żółte bloki mieszkalne, natomiast widzimy jeszcze biały wieżowiec oraz w tle dwie wieżyczki wychodzące z niższej budowli. Gdzieniegdzie przed nami możemy dostrzec drzewa, które wtapiają się w tło. Owe rośliny wyglądają na zziębnięte, gdyż mają cienkie gałązki oraz dość chude pnie. Są położone pomiędzy budynkami, a zbiornikiem wody, na małym pagórku przypominającym polanę. Tuż przy brzegu, po prawej stronie leży obszerny stos gałęzi. Całkiem w tle zdjęcia znajduje się prawie niewidoczne pole o żółtym kolorze z zielonymi krzakami ponad nim.

Autorka pracy na początku stosuje kompozycję horyzontalną, zarysowuje, co widoczne jest na pierwszym planie, i przechodzi do drugiego planu. Kiedy scharakteryzowała najbardziej widoczne elementy, zmienia kompozycję na hierarchiczną, aby rozbudować swój tekst, i opisuje mniejsze elementy, mniej istotne dla krajobrazu, takie jak drzewa czy gałęzie.

28. Zdjęcie przedstawia krajobraz miejski. Jego elementami są między innymi rzeka, a tuż za nią drzewa, kamienisty brzeg budynki i niebo.

$\mathrm{Na}$ pierwszym planie widnieje ciemnogranatowa rzeka wylewająca się na kamienisty brzeg porośnięty ciemnobrązowymi, gołymi drzewami. Odbijają się w niej rozmyte kształty budynków stojących tuż za nią. Wyróżniają się one najbardziej ze zdjęcia swymi różnorodnymi kształtami 
i kolorami. Wieżowce są rozmieszczone raczej po bokach zdjęcia. Ich dominującymi kolorami są między innymi biały, żółty, i odcień niebieskiego. Między nimi wyłania się katedra o kasztanowym kolorze i wieżach w kształcie stożka w kolorze miętowym. Po lewej stronie jednego z wieżowców, zza drzew wyłania się biało-czarny autobus. Na dachach wieżowców da się zauważyć anteny i różne odbiorniki. Po lewej stronie wież katedry, na dachu zamieszczona jest trzecia mniejsza wieżyczka również w kształcie stożka, lecz w kolorze czarnym.

Opis (przykład 28) zaczyna się od ogólnego zarysowania krajobrazu, poszczególne elementy wymienione są zgodnie z porządkiem horyzontalnym. Porządek ten jest kontynuowany w kolejnym akapicie, ale przechodzi w kompozycję hierarchiczną — podobnie jak w przykładzie 27, w którym po scharakteryzowaniu największych elementów uczeń wprowadza szczegóły. Szczegóły te podane są w takim samym porządku jak wcześniej opisane budynki, z którymi one sąsiadują lub których są częściami.

W sześciu pracach zastosowano kompozycję, którą można uznać za horyzontalną — uczniowie opisują po kolei każdy z planów fotografii:

29. W krajobrazie tym opisuję miasto na którym widać rzekę, dwa żółte budynki oraz wysoki biały hotel i duży kościół.

Rzeka jest bardzo szeroka a koło niej są drzewa na których nie ma liści dlatego zdjęcie krajobrazu którego opisuję jest zrobione jesienią. Za drzewami widać ulice i nadjeżdżający biały autobus $\mathrm{z}, \mathrm{w}$ tle widać mniejsze budynki.

30. Opisywany krajobraz, jest krajobrazem miejskim na którym bardzo dużo się dzieje. W oczy najbardziej rzuca się krystaliczne, piękne jezioro, odbijające w sobie budynki. Nad jeziorkiem znajduje się ziemia, z której wyrastają bezlistne drzewa. Na pierwszym planie wraz z jeziorem znajdują się wysokie budynki. Najwyższy z nich jest koloru białego, ale znajdują się tam czarne i miętowe paski. Budynek jest naprawdę ładny, znajduje się na nim dużo czarnego szkła, a na szczycie posiada punkt widokowy. Po lewej stronie są dwa bardzo podobne do siebie żółto-białe niższe budynki, które są mniej oszklone od pierwszego i może właśnie dlatego nie przypadły mi do gustu. Na drugim planie są głównie kamienice o bladych kolorach. Za nimi można dojrzeć dwie wieże o miętowym dachu. Niebieskie niebo znajdujące się nad nimi jest tak czyste jak mieszkanie po wizycie „perfekcyjnej pani domu".

Powyższe opisy różnią się długością, a co za tym idzie liczbą elementów, które się w nich pojawiły. Uczniowie zachowują jednak kompozycję horyzontalną i poszczególne elementy pojawią się w podobnej kolejności. Wyjątkiem jest przykład 29, w którym uczeń po ogólnym przedstawieniu krajobrazu rozwija jeszcze opis poszczególnych elementów, zachowując przy tym kolejność odpowiadającą planom fotografii.

Większość prac będących opisem krajobrazu ujętego na fotografii była uporządkowana i kompozycyjnie przemyślana. Okazuje się, że kiedy uczeń ma opisać fragment przestrzeni, nie ma problemu z uporządkowaniem tekstu w taki sposób, aby był on czytelny i ułatwiał zidentyfikowanie obrazu. Pomagają mu w tym również operatory usytuowania przestrzennego: za, przed, na pierwszym palnie, w tle, po lewej stronie itp. 


\subsection{Poziom zagłębienia tekstu}

\section{Opisy postaci}

W opisach postaci hipertematem jest zawsze opisywana osoba. Tematy zdań i poziom zagłębienia opisów jest natomiast różny.

W pierwszym zdaniu zawsze pojawia się hipertemat tekstu, ale nie zawsze jest on tematem incipitu — często stanowi jego remat, jak w poniższych przykładach:

31. Moim najlepszym przyjacielem jest [temat] Ania [remat].

32. Przedstawię wam teraz [temat] moją mamę [remat].

33. Moją najlepszą przyjaciółką jest [temat] Wiktoria, z którą znam się od pierwszej klasy [remat].

34. Moją najlepszą przyjaciółką jest [temat] Wiktoria M[...] [remat].

Kolejne zdania są zdaniami rematycznymi, informują o wieku, sylwetce itp., czyli w najogólniejszy sposób charakteryzują przedmiot opisu, tematem tych zdań na zasadzie następstwa tematycznego jest temat lub remat zdania incipitowego:

35. Moim najlepszym przyjacielem jest [temat 1] Ania [remat 1]. Ma ona trzynaście lat, jest blondynką o krótko ostrzyżonych włosach [temat 2 = remat 1 ; remat 2].

36. Przedstawię wam teraz [temat 1] moją mamę [remat 1]. Ma na imię Agnieszka i ma 39 lat [temat $2=$ remat 1 ; remat 2 ].

37. Moją najlepszą przyjaciółką jest [temat] Wiktoria, z którą znam się od pierwszej klasy [remat 1]. Wiktoria jest szczupłą, wysoką i długowłosą brunetką lat [temat $2=$ remat 1 ; remat 2].

38. Moją najlepszą przyjaciółką jest [temat] Wiktoria M[...] [remat]. Mieszka niedaleko mnie, dlatego często się spotykamy [temat $2=$ remat 1 ; remat 2 ].

Od ogólnego opisania osoby uczniowie przechodzą do charakteryzowania poszczególnych części ciała, pojawiają się więc nowe tematy, jak w przykładach:

39. Jej oczy są niebieskie, nos duży i zadarty, a usta małe, i czerwone.

40. Ma gęste, brązowe włosy, niebieskie, duże oczy oraz średni nos z piegami.

Zdania te są politematyczne; na zasadzie wyliczenia dodawane są w obrębie jednego wypowiedzenia kolejne jednostki składniowe, które mają odrębny temat. W przykładzie 39 są to: oczy, nos, usta. W przykładzie 40 z gramatycznego punktu widzenia tematem zdania powinna być opisywana osoba, jednak z pytań, jakie postawiono, testując podział tematyczno-rematyczny, wynika, że tematami są: włosy, oczy, nos - logiczniejsze są bowiem w tym przypadku pytania: „Jakie ma włosy?”, „Jakie ma oczy?”, „Jaki ma nos?” niż pytanie: „Co ma?”25. W dalszej części tekstu jest podobnie, zwłaszcza gdy uczniowie opisują ubiór, zainteresowania, zwyczaje wybranej przez siebie osoby. Chociaż podmiotem zdania (najczęściej domyślnym) jest właśnie ta osoba, to tematem będzie w takich przypadkach orzeczenie, a rematem dopełnienie:

${ }^{25}$ Por. J. Bartmiński, S. Niebrzegowska-Bartmińska, op. cit., s. 261-265. 
41. Lubi ubierać się w dres [nie garnitur].

42. Porusza się szybko, małymi krokami [a nie powoli].

Tematem zdań ponownie staje się hipertemat, kiedy uczniowie opisują charakter osoby:

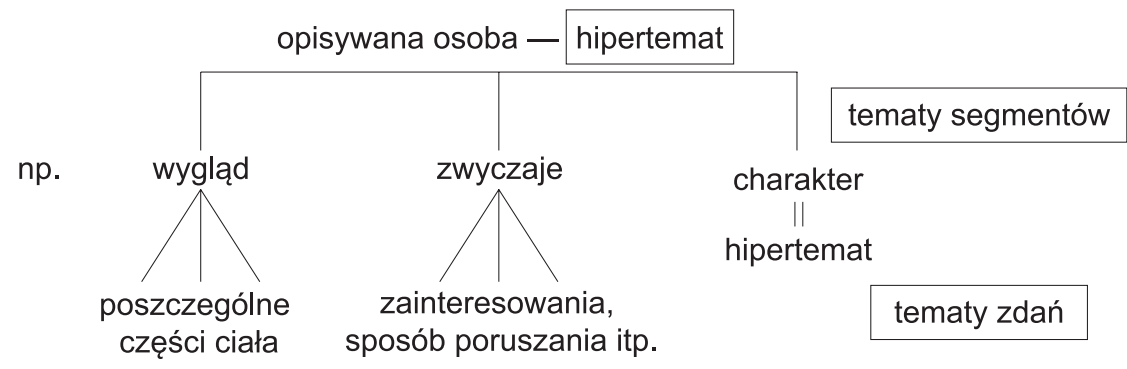

Schemat 1.

Źródło: opracowanie własne.

43. Zawsze jest energiczna a zarazem spokojna.

44. Moja mama jest zawsze radosna na jej twarzy zwykle widoczny jest uśmiech, jest też wysportowana, bardzo lubi sport.

Widać więc, że opisy postaci mają rozbudowaną strukturę tematyczno-rematyczną, można ją w dużym uogólnieniu przedstawić za pomocą schematu 1:

$\mathrm{Z}$ podziałem tematyczno-rematycznym wiążą się poziomy zagłębienia tekstu. Pierwszym poziomem jest jego hipertemat - czyli wszystkie zdania, które charakteryzują opisywaną osobę. Kolejny poziom to elementy, które składają się na całość opisywanego obiektu wraz z ich cechami. Trzecim poziomem w głąb będą te charakteryzowane elementy, które są częściami składowymi obiektów przypisanych do drugiego poziomu.

W opisach postaci najczęściej mamy do czynienia tylko z dwoma poziomami, zejście na poziom trzeci występuje zazwyczaj wtedy, gdy uczeń najpierw charakteryzuje całą twarz człowieka, a potem wyodrębnia jej elementy:

45. Mama [I poziom] ma okrągłą twarz [II poziom], a na niej niebieskie oczy [III poziom] z długimi czarnymi rzęsami [IV poziom], lekko różowe usta i zarumienione policzki [III poziom].

46. Ma owalną twarz [II poziom], po której spływają ciemne blond długie włosy [III poziom]. Ma duże brązowe oczy i ładne usta [III poziom]

47. Adama [I poziom] twarz jest podłóżna, a cera jasna [II poziom]. Na jego twarzy rzadko pojawia się uśmiech [III poziom].

W przytoczonych przykładach uczniowie najpierw podawali cechy twarzy człowieka, a potem uzupełniali swoją wypowiedź o informacje o poszczególnych jej częściach, zagłębiając się w ten sposób w szczegóły i tworząc kolejny poziom rozwinięcia tematycznego. Dodatkowo autor opisu zacytowanego w 45 przykładzie schodzi na czwarty poziom — charakteryzuje rzęsy jako element składowy oczu. 
Poza opisem twarzy rzadko występuje zagłębienie do trzeciego poziomu; można je zauważyć jeszcze przy charakteryzowaniu stroju:

48. Często zakłada na głowę czapkę z daszkiem [poziom II]. Jest ona przyozdobiona złotą literą F [poziom III].

49. Natomiast na treningi zakłada ciężki, masywny strój hokeisty [poziom II]. Ubranie, które ubiera składa się z ochraniaczy: na nogi, na pośladki, na ręce, na brzuch, na ramiona, na brzuch [poziom III]. Na głowę zakłada kask, a na stopy łyżwy [poziom III].

W przykładzie 48 uczeń informuje, że opisywana osoba nosi czapkę z daszkiem, a następnie precyzuje, jak ona wygląda i podaje kolor zdobiącej ją litery, czyli elementu składowego bardziej szczegółowego w stosunku do całości. W przykładzie 49 natomiast uczeń wprowadza najpierw ogólnie charakteryzowany przedmiot, przyporządkowując go do konkretnego gatunku: „strój hokeisty”, a następnie uszczegóławia opis, wymieniając elementy składowe tego stroju.

Uczniowie rzadko tworzą wielopoziomowe opisy postaci (ponad dwadzieścia prac miało tylko dwa poziomy zagłębienia tekstu), dążą raczej do uogólnienia, syntetyzują podawane informacje. Zapewne uwzględnienie jak największej liczby opisywanych elementów potęguje obrazowość tekstu, świadczy też o wrażliwości ucznia na szczegóły, ale wymaga użycia odpowiednich środków językowych, które pomogą uporządkować charakteryzowane elementy. Jednak w niektórych przypadkach nadmiar szczegółów może wprowadzić chaos i wielosłowie, a także pogłębić wyliczeniowy charakter opisu.

\section{Opisy przedmiotów}

Zagłębianie w opisie przedmiotu w dużej mierze zależy od tego, jaka rzecz stała się tematem tekstu. Wydaje się więc, że im przedmiot bardziej złożony, im większa liczba elementów, które go tworzą, tym więcej poziomów zagłębienia.

W niemal połowie prac (12 z 23) uczniowie opisują przedmiot jako całość, nie wprowadzając szczegółowej charakterystyki elementów składowych:

50. Opisuję obraz z Portugalii. Jest duży i w kształcie prostokąta. Ma dużo kolorów i przedstawia najładniejszą uliczkę w mieście. Jest zrobiony z specjalnego materiału do malowania. Bardzo mi się podoba, i lubię na niego patrzeć.

51. Mój piórnik jest w kształcie tuby. Jest wykonany z brezentu. Zdobią go auta „Hot Wheels”.

Niestety, w niektórych miejscach materiał prześwituje. Mieszkają w nim różne rzeczy: sprężynka, karteczki, papierki, rysiki, kredki, gumki, gumko-strugaczka, nożyczki, ołówki, szczęśliwy ołówek, długopisy, zabezpieczacz do nożyczek, klej, kontomież, korektor w taśmie, piórka kulkowe, spinacz, osie z plastiku i coś do smyczki.

Tak wygląda najciekawszy, najfajniejszy, najładniejszy, najbogatszy w przedmioty piórnik na świecie.

W przykładzie 50 nie występują żadne określenia, które można by uznać za charakterystykę elementów składowych opisywanego obrazu. Choć pojawiają się przymiotniki nieodnoszące się bezpośrednio do rzeczownika „obraz”, to nie wprowadzają one żadnych dokładnych informacji na ich temat. W przykła- 
dzie 51 uczeń wylicza wiele elementów składowych, ale żadnego z niech nie charakteryzuje.

W jedenastu z dwudziestu trzech prac obok cech, które dotyczą całego przedmiotu, uczniowie przynajmniej raz podają cechę wymienianych przez siebie części składowych opisywanej rzeczy:

52. Opisuję deskorolkę.

Jest kształtu spłaszczonego koła, z góry jest czarna a od dołu szara. Ma białe, plastikowe kółka i jest dosyć ciężka. Jest zrobiona $z$ drewna. Jeździ szybko na równym podłożu. Jest super!

53. Codziennie chodzę z nim do szkoły. To piórnik. Przechowuję tam moje kredki, pisaki, gumki itp.

Jest podłużny (prostokątny), wykonany z brezentu. Jego kolory to róż i pomarańcz. Ma ozdobny, także pomarańczowy suwak. Często się zacina, bo służy mi już 4 lata. Na środku lśni napis „Diddlina”.

Jest dla mnie bardzo ważny, bo gdzie indziej miałabym to wszystko przechowywać?

W przykładzie 52 uczeń oprócz cech deskorolki (hipertemat tekstu) charakteryzuje również jej kółka, nie wydziela jednak tych informacji w osobnym zdaniu, ale łączy je z określeniem wagi przedmiotu. Wyraźniej zarysowane zejście na drugi, bardziej szczegółowy poziom opisu widać w przykładzie 53, w którym uczennica opisowi zamka poświęca aż dwa osobne zdania, tworzy w ten sposób mikrotemat wyabstrahowany z całości, czyli piórnika. Podobny zabieg zauważyć można w przytoczonym przykładzie:

54. Opiszę kubek, który dostałam na urodziny. Mój kubek jest gliniany. Ma kolor niebieski w białe śnieżki. Jest owalny i ma dużą rączkę do trzymania. Ma na przodzie brązowego reniferka z kraciastą wstążką. Kolor oczu ma niebieski. Renifer jest wesoły i się cieszy, gdy ktoś z niego pije. Moja własna ocena: bardzo mi się podoba bardzo lubię z niego pić cieplutką herbatkę z mienty.

Uczennica tworzy złożony opis elementu składowego (rysunku na kubku), charakteryzuje go jako całość oraz wyodrębnia kolejne elementy składowe (wstążka, oczy, metaforycznie ujęte zachowanie ,jest wesoły i cieszy się, gdy ktoś z niego pije") — powstaje w ten sposób opis w opisie - mamy do czynienia z kompozycją szkatułkową i trzecim poziomem zagłębienia opisu.

Zagłębienie rozwinięcia tematycznego w opisach przedmiotów jest zróżnicowane i zależy, po pierwsze, od tego, jaki przedmiot został opisany, a po drugie, od indywidualnego spojrzenia ucznia. Panuje jednak tendencja do pobieżnego opisania przedmiotu, bez określania jego cech indywidualnych, przez co opis staje się niepełny. Nawet te opisy, które można uznać za pogłębione, nie są na drugim poziomie wystarczająco rozwinięte.

\section{Opisy krajobrazu}

Opisy krajobrazu są bardziej rozbudowane od poprzednich typów opisów, gdyż wymagają scharakteryzowania większej liczby elementów składowych, w ich obrębie tworzy się też więcej poziomów zagłębienia. Głębokość deskrypcji w tym przypadku łączy się z przyjętym porządkiem elementów opisu. 
Podstawą każdego z opisów jest ogólne przedstawienie opisywanej przestrzeni. Uczniowie zaczynają od określenia, jaki typ krajobrazu lub jakie miejsce jest tematem ich tekstu, a następnie wymieniają i opisują jego elementy składowe, uszczegóławiając deskrypcję i tworząc kolejne poziomy zagłębienia.

$\mathrm{Na}$ pierwszym poziomie znajduje się hipertemat, drugim poziomem jest przedstawienie, z czego składają się poszczególne plany, trzeci poziom stanowią szczegółowe opisy obiektów znajdujących się na fotografii - nadawcy komunikatu często charakteryzują je aż do najmniejszych widocznych detali.

55. Na zdjęciu zamieszczonym przede mną wyraźnie widać miejski krajobraz jesienny, w którym na pierwszym planie znajduje się jezioro, a w jego odbiciu można zauważyć nieco rozmazane odbicie stojących dalej wysokich budynków i katedry.

Na brzegu widać wysuszone pozostałości po krzewach, roślinach, a za nimi bezlistne, drzewa które dodają nieco tajemniczości temu zdjęciu. Natomiast wysokie ich gałęzie zasłaniają mniejsze, mało już widoczne budynki czy też instytucje, które wraz z trzema wierzowcami i zapewne zabytkową katedrą znajdują się na drugim planie a ten mimo że nie jest wcale ładny a napewno ładniejszy od pierwszego to zapewne jest ciekawszy. Część miasta, którą widzę, wygląda na opuszczoną, co wprowadza mroczny nastrój. W dwóch znajdujących się obok siebie, po lewej stronie żółtawych jak przypuszczam budynkach mieszkalnych, które to posiadają balkony, nie widać śladów jakich kolwiek mieszkańców, a trzeci znajdujący się lewej stronie mieszkańców, a trzeci znajdujący się po lewej stronie widoczny budynek jest jak myślę hotelem lub instytucją pracy. Różni się od pozostałych jest nowoczesny, ma białą elewację przeplataną szkłem. Po między wierzowcami widać dość ładną katedrę pokrytą czerwono-brązową cegłą i błękitno-zielonym dachem z dodatkową wierzą, obydwie zakończone są znakiem krzyża.

Krajobraz ten nie przypadł mi za specjalnie do gustu, ale myślę, ze tak jak każde miejsce na ziemi ma swój klimat.

Autorka wprowadza aż trzy poziomy zagłębienia opisu. Pierwszy stanowi ogólna charakterystyka krajobrazu, zawarta głównie w pierwszym akapicie, do drugiego należą zdania ogólnie opisujące wycinek przestrzeni: „Na brzegu widać wysuszone pozostałości po krzewach, roślinach, a za nimi bezlistne, drzewa które dodają nieco tajemniczości temu zdjęciu”; „Część miasta, którą widzę, wygląda na opuszczoną, co wprowadza mroczny nastrój”; trzeci poziom to szczegółowy opis budynków: „Różni się od pozostałych — jest nowoczesny, ma białą elewację przeplataną szkłem. Po między wierzowcami widać dość ładną katedrę pokrytą czerwono-brązową cegłą i błękitno-zielonym dachem z dodatkową wierzą, obydwie zakończone są znakiem krzyża”. Uczennica świadomie zagłębia opis, chce jak najdokładniej przedstawić to, co widzi, z zachowaniem porządku od ogólnego po szczegółowe, dzięki czemu opis będzie czytelny.

Opisy krajobrazu są zazwyczaj zgodne z zdefiniowaną przez Wilkonia „feudalną" drabiną deskrypcji ${ }^{26}$, która przedstawia się następująco:

\footnotetext{
${ }^{26}$ A. Wilkoń, op. cit., s. 141.
} 


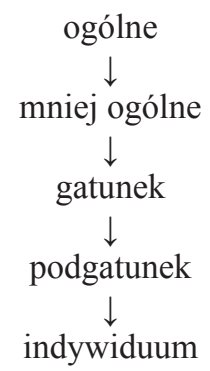

i wiąże się nie tylko z zagłębieniem opisu, lecz także porządkiem jego elementów.

Pogłębienie opisu pokazuje indywidualne spojrzenie ucznia na świat (każdy z nich dostrzega inne elementy) oraz wzmacnia obrazowość tekstu, dzięki czemu nietrudno rozpoznać opisywany krajobraz. Wiele opisów z bardzo szczegółowym i pogłębionym rozwinięciem tematycznym świadczy o wrażliwości uczniów i wysokiej kompetencji analizowania i syntezowania.

\section{Podsumowanie}

Dużą trudnością dla uczniów było pogłębione rozwinięcie tekstów. Często przedmioty opisu traktowane były powierzchownie, podawano mało elementów składowych i nie charakteryzowano ich wystarczająco, na przykład krótkie, kilkuzdaniowe opisy przedmiotów informowały tylko o głównych ich cechach, w wyniku czego były mało obrazowe. Podobnie było z opisami postaci, w których część dotycząca wyglądu sprowadzała się do wymienienia części ciała i określania ich jednym, dwoma atrybutami. Uczniowie w swoich pracach o wiele więcej miejsca poświęcali mentalności osoby niż jej aparycji, przez co opisy bliższe były charakterystyce postaci. Na taki stan rzeczy wpłynęły polecenia i tematy — opis matki, osoby, która imponuje, czy przyjaciela pociąga za sobą chęć zaakcentowania wyjątkowości tej postaci, wyjaśnienia przyczyny wyboru, a to wiąże się przede wszystkim z charakterem. Najbardziej z wszystkich rozbudowane były opisy krajobrazu, co bez wątpienia było efektem sytuacji dydaktycznej, w jakiej zostały sporządzone. Powstały one jako tekst diagnostyczny — uczniowie po odpowiednim przygotowaniu w czasie jednej lekcji opisywali wyświetlany na tablicy pejzaż. Można więc stwierdzić, że ogląd przedmiotu w trakcie tworzenia jego opisu ułatwia analizę i pozwala uwzględnić większą liczbę szczegółów.

Z głębokością i bogactwem rozwinięcia tematycznego wiąże się również porządek elementów opisu. Najczęściej, niezależnie od odmiany opisu, uczniowie stosują układ hierarchiczny, który następnie uzupełniają układem odpowiednim dla tematu, a więc dla opisu postaci jest to układ wertykalny, od góry do dołu, a dla opisu krajobrazu - układ horyzontalny. Jednak uczniowie nie zawsze stosują tę zasadę. Zdarza się, że nie zachowują obranego porządku i wracają do elemen- 
tów już opisywanych albo znacznie odbiegają od kolejności przyjętej we wzorze kompozycyjnym. Czasem brakuje w ich pracach spójności treściowej wewnątrz akapitu. Takie nieuporządkowanie świadczy o braku zamysłu kompozycyjnego, uczniowie piszą to, co w danym momencie im się przypomni, nie poddając swoich tekstów refleksji.

\section{Bibliografia}

Bar J., Szkolne formy wypowiedzi, [w:] Wybrane zagadnienia edukacji polonistycznej, red. H. Kurczab, U. Kopeć, E. Kozłowska, Rzeszów 2002.

Bartmiński J., Niebrzegowska-Bartmińska S., Tekstologia, Warszawa 2009.

Borowkin S., Słownik terminów piśmienniczych, Kielce 1997.

Duszak A., Tekst, dyskurs, komunikacja międzykulturowa, Warszawa 1998.

Kowal J., O sztuce pisania wypracowań. Dialog, list, opis, opowiadanie, rozprawka, sprawozdanie, streszczenie, charakterystyka postaci, Kielce 1994.

Kulpa J., Pasterniak W., Metodyka nauczania języka polskiego, Warszawa 1977.

Nagajowa M., ABC metodyki języka polskiego dla początkujacych nauczycieli, wyd. 2 popr., Warszawa 1995.

Nagajowa M., Jak uczyć języka polskiego w klasach 4-6. Poradnik metodyczny do podręczników „Stowo za stowem”, ,, Stowa zwykte i niezwykte”, ,Stowa i świat”, Warszawa 1995.

Słownik terminów literackich, red. J. Sławiński, wyd. 3 poszerz. i popr., Wrocław 2000.

Wilkoń A., Spójność i struktura tekstu. Wstęp do lingwistyki tekstu, Kraków 2002.

Wiśniewska H., Łatwa i trudna kompozycja pisemnych wypracowań uczniowskich, [w:] Wokót szkoty i nauczyciela. Skrypt dla studentów filologii polskiej, red. H. Wiśniewska, J. Plisiecki, Lublin 1997.

Witosz B., Opis w prozie narracyjnej na tle innych odmian deskrypcji. Zagadnienia struktury tekstu, Katowice 1997.

Żydek-Bednarczuk U., Wprowadzenie do lingwistycznej analizy tekstu, Kraków 2005. 